\title{
EFFECT OF CLIMATE CHANGE ON POTENTIAL EVAPOTRANSPIRATION IN THE UPPER BEAS BASIN OF THE WESTERN INDIAN HIMALAYA
}

\author{
Seema Rani ${ }^{1}$, S. Sreekesh ${ }^{2,}$, , Prameela Krishnan ${ }^{3}$ \\ ${ }^{1}$ Department of Geography, Miranda House, University of Delhi, New Delhi, India - seemarani.dse@gmail.com \\ ${ }^{2}$ Centre for the Study of Regional Development, Jawaharlal Nehru University, New Delhi, India - sreekesh@mail.jnu.ac.in \\ ${ }^{3}$ Division of Agricultural Physics, Indian Agricultural Research Institute, New Delhi, India - prameelakrishnan@yahoo.com
}

Commission III, WG III/10

KEY WORDS: Climate change, Potential evapotranspiration, agricultural water requirement, SWAT

\begin{abstract}
:
Appraisal of potential evapotranspiration (PET) is needed for estimating the agricultural water requirement and understanding hydrological processes in an arena. Therefore, aim of the paper was to estimate the PET in the upper Beas basin, situated in the Western Indian Himalaya, under future climate change scenarios (by mid-21st century). Climate data (1969-2010) of Manali, Bhuntar and Katrain were obtained from India Meteorological Department (IMD) and the Indian Agricultural Research Institute (IARI). Landsat data were used for mapping land use/land cover (LULC) conditions of the basin through decision tree technique. Elevation detail of the catchment area is derived from the Cartosat-1 digital elevation model (DEM). Simulations of PET were done by the Soil and Water Assessment Tool (SWAT) model. The model was calibrated using the average monthly discharge data from Thalout station. The study found fluctuations in PET under different climate change scenarios. It is likely to increase in near future owing to the rise in temperature. The higher water demand can be met from the excess snowmelt water reaching the lower basin area during the cropping seasons. This study will be helpful to understand water availability conditions in the upper Beas basin in the near future.
\end{abstract}

\section{INTRODUCTION}

\subsection{Background}

Climate change is an important factor in controlling the hydrological regime of a catchment as it makes alterations in the components of the hydrological cycle and influence the availability of water resources (Tomer and Schilling 2009, Githui et al., 2009, Lu et al., 2009, Cheema and Bastiaanssen 2010, Singh and Gosain 2011, Sood et al., 2013, Luo et al., 2013, Prasena and Shrestha 2013). Evidences of climate variability are observed with different magnitude around the world. According to the IPCC (2014), the global average temperature showed a rise of about $0.89^{\circ} \mathrm{C}$ during 1901-2012. Changes in air temperature were also found in India (Singh et al., 2008, Pal and Al-Tabbaa, 2010). Arora et al., (2005) found a rise in annual mean, maximum and minimum air temperature at the rate of $0.422^{0} \mathrm{C}, 0.92^{0} \mathrm{C}$ and $0.09^{0} \mathrm{C}(100 \text { year })^{-1}$, respectively during 1940-2000 at all India level. The study also found an increase in annual mean air temperature in southern and western India at the rate of $1.06^{\circ} \mathrm{C}$ and $0.36^{\circ} \mathrm{C}(100 \text { year })^{-1}$, respectively, while north Indian plains shown a decline of $0.38^{0} \mathrm{C}\left(100\right.$ year $^{-1}$ in annual mean air temperature. It shows regional variations of trend in annual mean air temperature in India. Dash and Hunt (2007) reported a rise in annual mean temperature by $0.5^{\circ} \mathrm{C}$ during $1901-2003$ at all India level. This warming trend has been linked to a rise in maximum temperature. The study also indicated a rise in minimum air temperature of winter and post-monsoon by $0.4^{0} \mathrm{C}$ and $0.7^{\circ} \mathrm{C}$ respectively. The study further revealed that in the last two decades, the maximum temperature over North India is rising.
Jain and Kumar (2012) also found a rise of $0.51^{\circ} \mathrm{C}, 0.72^{\circ} \mathrm{C}$ and $0.27^{\circ} \mathrm{C}$ per 100 years in annual mean, maximum and minimum temperature in India, respectively during 1901-2007. It indicates that maximum air temperature is rising faster than the minimum air temperature.

Western Indian Himalaya has also been experiencing warming over the long time. Bhutiyani et al., (2007) found $1.6^{\circ} \mathrm{C}$ warming $\left(0.16^{0} \mathrm{C} /\right.$ decade $)$ over the Northwest Indian Himalaya in the last century. Dash et al., (2007) reported a rise $0.9^{\circ} \mathrm{C}$ in air temperature over 102 years (1901-2003) in the Western Indian Himalaya particularly after 1972. Dimri and Dash (2012) likewise found a warming trend, particularly in winter temperature during 1975-2006 in the Western Indian Himalaya, with the greatest observed increase in maximum temperature $\left(1.1-2.5^{\circ} \mathrm{C}\right)$. It was observed that the annual mean air temperature in the upper Beas river basin has increased significantly at rate of $0.031^{\circ} \mathrm{C} /$ year during 1980-2010 (Rani, 2014). Rani and Sreekesh (2018) found a significant rise in the annual mean minimum and maximum air temperature at Manali and Bhuntar during 1980-2010. The study further reported a rise in annual mean air temperature at Manali and Bhuntar at the rate of $0.03^{\circ} \mathrm{C} /$ year and $0.05^{\circ} \mathrm{C} /$ year respectively during the same period. Minimum temperature shown more variability than the maximum temperature in the Western Indian Himalaya.

Rising temperature will influence the constituents of the hydrological cycle. Potential evapotranspiration (PET) is one of the important components because its estimation is important in the assessment of crop water requirement. It can likewise

Corresponding author 
determine the agricultural operation of an arena. Effect of warming on PET is evaluated at different spatial scale (Rong et al., 2013, Sood et al., 2013). A rise in PET was found with rise in air temperature, though regional variations in the change of PET have also been reported. In India, PET was also estimated under future climate change conditions and a rise in PET was found due to future warming (Chattopadhyay and Hulme, 1997). A rise in PET under potential climate change in the Chaliyar river basin (Kerala) of India was founded by the end of the 21st century (Raneesh and Santosh, 2011). An increase in average annual evapotranspiration (ET) between 5 to 6 per cent was estimated under future climate change in Upper Sind River basin (Narsimlu et al., 2013). An evaporation process under varying snow cover conditions was well explained by Bengtsson (1980). According to this study, total amount of evaporation can vary between $10-20 \mathrm{~mm}$ during the whole snow covered season. Singh and Bengtsson (2005) distinguished the effect of warming on evaporation among rain fed, snow fed and glacier fed basin of the Satluj River located in the western Himalayan region. The study found a maximum increase in evaporation for snow fed basins. PET analysis under warming conditions is very important for the Himalaya where agriculture is the main livelihood of the people. However, limited studies have been done in the region, particularly in snow fed basins to examine the effect of future climate change on PET. Considering the need of more such studies in the Himalaya, the present study aimed to estimate the PET in the upper Beas river basin under future climate change scenarios in the near future (by mid- $21^{\text {st }}$ century).

\subsection{Study Area}

The upper Beas basin was selected for the present study, which is located in the Western Indian Himalaya (Figure 1). This basin is drained by the Beas River, a tributary of the Indus River. It originated from the Beas Kund $(4085 \mathrm{~m})$ which lies in the lower Himalayan zone. The length and catchment area of the river (up to Pandoh dam) is approximately $116 \mathrm{~km}$ and 5300 $\mathrm{km} 2$ respectively. Approximately 15 per centime of the survey area is under the permanent snow (BBMB, 1988). The average monthly temperature in the catchment area is below $5^{\circ} \mathrm{C}$ in January and about $25^{\circ} \mathrm{C}$ in July. Weather varies with the altitudinal variation $(840-6582 \mathrm{~m})$ of the catchment. Mean elevation in the study area is approximately $3400 \mathrm{~m}$.

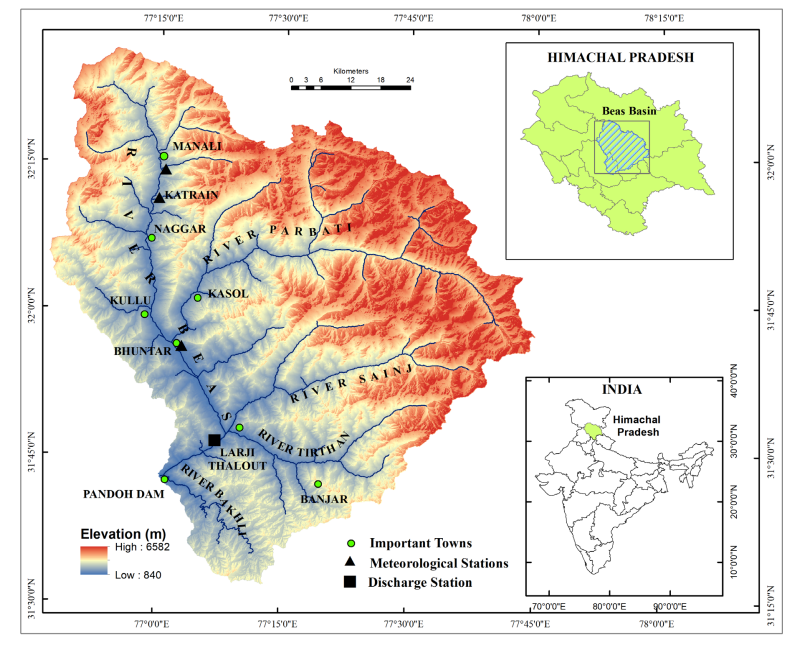

Figure 1. Location of upper Beas basin with elevation and meteorological stations
The soil in the basin has been classified into broadly four categories viz soil in the valley area (Entisols, Inceptisols), midhill, mild temperate areas (Entisols, Inceptisols and Mollisols), high-hill temperate areas (Alfisols and Inceptisols) and high hill wet temperate areas. The basin is dominated by forest and snow cover. The vegetation in the area varies from deciduous in the lower part to alpine in the higher part. The basin has near about 400000 population and majority of their livelihood depends on the horticulture (apple cultivation) and tourism (Census of India, 2011). Wheat is a main cereal crop of the area. As per the government record, the crop irrigated area is around 4.8 per cent of the catchment during 2011-12. The water resources of the region include rivers, streams, springs and glaciers. The Beas River receives the highest flow of about 55 per cent during monsoon followed by pre-monsoon and out of total discharge, 65 per cent is contributed by rainfall (Kumar et al., 2007). Surface water is the primary source for meeting the agriculture requirements.

\section{MATERIAL AND METHODS}

The study has applied Soil and Water Assessment Tool (SWAT) for simulating the hydrological conditions of the basin in GIS environment. The model requires climate, altitude, land cover and land information. India Meteorological Department (IMD) climate data (daily air temperature, rainfall, wind speed and relative humidity) of Manali (1969-2010) and Bhuntar (1969-2010) were obtained for the study. Katrain (1985-2015) climate data has been acquired from the Indian Agricultural Research Institute (IARI). Elevation data of the Cartosat-1 digital elevation model (DEM) of $30 \mathrm{~m}$ were taken from the Bhuvan of Department of Space, Indian Space Research Organization (ISRO) and National Remote Sensing Centre (NRSC) for analysing the photographic properties of the basin. Satellite image (Landsat 5, Path/Row 147/038, dated11/16/1991) (NASA, 2014) for preparing land cover map (using decision tree technique) of the area was acquired from the global visualization viewer of United States Geological Survey (USGS). Soil map and its properties (physical and chemical) were taken from a soil report (SLUSI, 2013). Thalout station discharge data for the period 1971-2002 was taken from the Ghorpa hydel project report for SWAT model calibration and validation. Seasonal analysis of PET in the study was also carried out by adopting a classification of seasons, namely winter (Dec-March), pre-monsoon (April-June), monsoon (JulySep) and post-monsoon (Oct-Nov) (Jain et al., 2009).

\subsection{Land use/Land cover (LULC) map}

Land cover map is an essential input to the SWAT model. Image atmospheric correction was performed by using dark object subtraction (DOS) method (Chavez, 1988). Base map of the basin was prepared from the toposheet of Survey of India (SoI). Then, decision tree was prepared in ENVI 5.2 software to classify the image by using spectral separability tools and indices such as a normalized difference built-up index (NDBI), water ratio index (WRI), normalized difference snow index (NDSI) and normalized difference vegetation index (NDVI). On the basis of the LULC classification scheme of National Remote Sensing Centre (NRSC) and Indian Space Research Organization (ISRO) (NRSC and ISRO, 2011), seven classes were decided, namely (i) built-up area, (ii) cultivated land, (iii) forest, (iv) grassland, (v) barren/unculturable/wasteland (BUW), (vi) water bodies and (vii) snow. Accuracy of LULC was assessed using an error matrix (Congalton, 1991) and 
Kappa (K) coefficient (Cohen, 1960). The overall accuracy of the land cover map of the basin is 85 per cent and its kappa coefficient is 0.82 , suggesting better results.

\subsection{Hydrological Modelling}

PET of the basin was estimated under different climate change scenarios, using the SWAT. It is a basin level distributed hydrological model (Neitsch et al. 2002). Beas river basin was demarcated and its 57 sub basins were created by taking threshold size of $50 \mathrm{~km}^{2}$. Hydrological response units (HRUs) were generated on the basis of land cover, slope and soil. The seven-land cover and twenty soil classes of the basin were considered for the modelling. For HRUs delineation, the basin's slope is divided into four divisions namely, (i) $<10$, (ii) $10-15$, (iii) $15-25$ and (iv) $>25$ per centime. Major portion of the basin falls in the fourth class, indicating steep to very steep side.

It is indispensable to provide elevation band detail in a mountain basin for calculating the rainfall and temperature for each elevation band as a function of respective lapse rates (Grusson et al., 2015). Hence, eight elevation bands were selected for the model, based on mean snow cover area (SCA) of the basin for the period 2000-2015 (Rani, 2017). Climate data of Manali, Bhuntar and Katrain were used to set up the weather model within the SWAT model environment. The surface flow was calculated using the soil conservation service (SCS) method (Neitsch et al. 2011). The Penman-Monteith method was applied for PET computation as its formula uses almost all weather parameters and appropriate for quantifying the effect of climate change on the components of basin hydrology.

\subsection{SWAT Model Parametrization}

The SWAT model was run for the period 1974-2010 and the initial five years as warm up period. Model calibration and validation was done for the periods 1985-1995 and 1996-2002 respectively. Mean monthly-observed discharge data of the Thalout station were used for the model calibration (Figure 1). Total eighteen parameters were chosen for calibrating the hydrological behaviour of the model. The letter ' $\mathrm{r}$ ' and ' $\mathrm{v}$ ' shows the relative change (\%) and value replace (absolute change) in the parameters respectively. Parameters of snow and elevation were calibrated manually using observed records. Values of snow related parameters were replaced by new values (given in brackets) namely (a) Rain/snow threshold $\left(0^{\circ} \mathrm{C}\right)$, (b) Maximum melt coefficient $\left(5^{0} \mathrm{C} / \mathrm{mm} /\right.$ day $)$, (c) Minimum melt coefficient $\left(2^{0} \mathrm{C} / \mathrm{mm} /\right.$ day $)$, (d) Snowpack temperature lag factor (0.68), (e) Snowpack temperature melt factor (1), (f) Areal snow coverage threshold CV100 (0.68) and (g) Areal snow coverage threshold CV50 (0.5). Elevation band related parameters include (a) Precipitation lapse rate $(20 \mathrm{~mm} / \mathrm{km})$, (b) Temperature lapse rate $\left(6^{0} \mathrm{C} / \mathrm{km}\right)$ and (c) Snow water content (30-200 mm).

Hydrological parameters were calibrated with the calibration/uncertainty program (SWAT CUP) using the Latin hypercube one-factor-at-a-time (LH-OAT) in sequential uncertainty fitting (SUFI2) (Abbaspour et al., 2015a, Abbaspour et al., 2015b). Hydrological parameters include (a) Runoff curve number for moisture condition II (r) (-0.15), (b) Groundwater delay (v) (11.9 days), (c) Surface run-off lag time (v) (9.6 days), (d) Manning's roughness for overland flow (v) (4.2), (e) Average slope steepness (r) $(-1.8 \mathrm{~m} / \mathrm{m})$, (f) Threshold depth of water in the shallow aquifer required for return flow to occur (v) $(23 \mathrm{~mm}),(\mathrm{g})$ Threshold depth of water in the shallow aquifer for "revap" or percolation to deep aquifer to occur (v) (964.5 mm) and (h) Ground revap coefficient (v) (0.04).

The model's uncertainty level was tested using coefficient of determination $\left(\mathrm{R}^{2}\right)$ and Nash-Sutcliffe (NS) (Nash and Sutcliffe, 1970, Moriasi et al., 2007). $\mathrm{R}^{2}$ and NS of discharge during calibration period were observed as 0.65 and 0.63 respectively (Table 1). $\mathrm{R}^{2}$ and NS coefficients for the both calibrated and validated periods suggest the acceptable model performance in simulating the hydrological conditions in the watershed. The graph presents the best simulation flow for the calibration period after running the model for 500 times by taking sensitive parameters of the basin (Figure 2). The model's simulated discharge nearly coordinated with the observed mean monthly discharge during the calibration period. However, peak discharge during the monsoon season is under-predicted. According to some studies, SWAT model is unable to simulate extreme events and often under predicts the peak flows (Chu and Shirmohammadi 2004, Tolson and Shoemaker, 2004).

\begin{tabular}{|c|c|c|c|c|}
\hline \multirow{2}{*}{$\begin{array}{l}\text { Simulation } \\
\text { period }\end{array}$} & \multicolumn{2}{|c|}{$\begin{array}{l}\text { Mean monthly discharge } \\
\left(\mathrm{m}^{3} / \mathrm{s}\right)\end{array}$} & \multirow[t]{2}{*}{$\mathrm{R}^{2}$} & \multirow[t]{2}{*}{ NS } \\
\hline & Observed & Simulated & & \\
\hline $\begin{array}{l}\text { Calibration } \\
(1985-1995)\end{array}$ & 217 & 207 & 0.65 & 0.65 \\
\hline $\begin{array}{l}\text { Validation } \\
(1996-2002)\end{array}$ & 207 & 202 & 0.64 & 0.61 \\
\hline
\end{tabular}

Table 1. Mean, standard deviation, $\mathrm{R}^{2}$ and Nash-Sutcliffe of the observed and simulated discharge of the basin

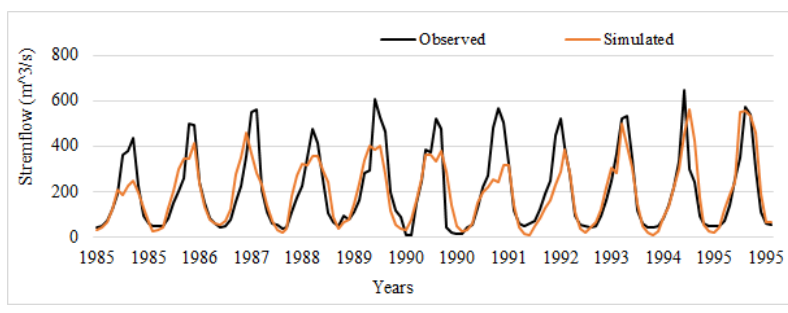

Figure 2. Model calibration results at Thalout in the upper Beas Basin

\subsection{Future Climate Change Scenarios}

The synthetic method was selected for creating climate change scenarios because of lack of reliable regional weather data for downscaling the General Circulation Models (GCMs) at basin scale (Feenstra et al., 1998). This method is well accepted in the current literature (Islam, 2012, Lirong, 2012, Liu, 2014, Musau, et al., 2015). Rising mean air temperature $\left(0.031^{\circ} \mathrm{C} /\right.$ year $)$ in the upper Beas basin was observed which may lead to a warming of about $1.27^{\circ} \mathrm{C}$ by mid-2 $1^{\text {st }}$ century (Rani and Sreekesh, 2018). Approximately $2.4^{\circ} \mathrm{C}$ rise in mean air temperature and 10.2 per cent change in annual rainfall was predicted in the state of Himachal Pradesh (where the Beas River flows) by 2050 (Bal et al., 2016). Considering the previous studies' estimation of climate change in the area, eight future climate change scenarios were decided for the study (Table 2). Zero in climate change scenarios means no change and that parameter is assumed constant. All the climate change scenarios were run for the period 1974-2010 with modified temperature and rainfall 
conditions with the help of weather adjustment parameters in the model (Neitsch et al. 2011).

\begin{tabular}{ccccccccc}
\hline $\begin{array}{c}\text { Climate } \\
\text { change } \\
\text { scenarios }\end{array}$ & $\mathrm{C} 1$ & $\mathrm{C} 2$ & $\mathrm{C} 3$ & $\mathrm{C} 4$ & $\mathrm{C} 5$ & $\mathrm{C} 6$ & $\mathrm{C} 7$ & $\mathrm{C} 8$ \\
\hline $\begin{array}{c}\text { Mean air } \\
\text { temperatur } \\
\mathrm{e}\left({ }^{0} \mathrm{C}\right)\end{array}$ & 2 & 3 & 0 & 0 & 2 & 2 & 3 & 3 \\
$\begin{array}{c}\% \text { change } \\
\text { in rainfall }\end{array}$ & 0 & 0 & 5 & 10 & 5 & 10 & 5 & 10 \\
\hline
\end{tabular}

Table 2. Selected future climate change scenarios for the upper Beas basin

\section{RESULTS AND DISCUSSION}

Future changes in climate (air temperature and precipitation) will have an effect on the components of the hydrological cycle, such as PET, soil moisture storage, surface flow, water yield etc. which determines the water availability in a region. Thus, it is crucial to understand the hydrological conditions of the basin in present and near future. In the present study, the SWAT hydrological model is used to understand the possible changes in the PET, which is one of the important components of the basin hydrology under different climate change scenarios by mid- $21^{\text {st }}$ century. However, land use changes will surely happen in the basin in the near future, the present study assumed it to be stable in the SWAT model. LULC conditions of the basin in the year 1991 were considered in all the simulations corresponding to calibration period. Forest (34 per cent) dominated the basin followed by snow (26 per cent) (Figure 3 ). Evaporation will be more from the snow fed basin compared to others. Transpiration will be more from the sub basins dominated by forest.

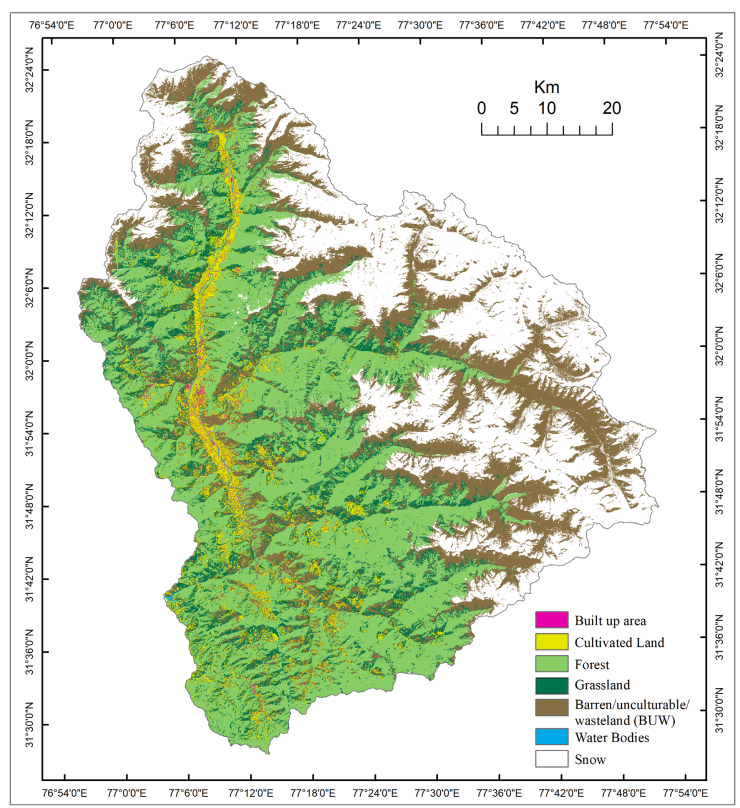

Figure 3. Land use/land cover conditions of the upper Beas basin in the year 1991

BUW covers an area of about 23 per cent of the basin followed by grassland. BUW changes with the variations in the extent of snow cover in the basin. Cultivated land constitutes about less than 5 per cent of the basin area, indicating less influencing land use in controlling the hydrological behaviour of the basin. Cultivated areas in the basin are mainly along valleys namely, Kullu, Parbati and Sainj. The principal crop of the area is Wheat followed by Maize, Rice and Barley. Apple is a main horticultural crop of the region.

The basin received a mean annual precipitation and water yield of about $1200 \mathrm{~mm}$ and $1086 \mathrm{~mm}$ respectively during the baseline period. During the same period, mean annual ET and PET of the watershed is found about 27 and $89 \mathrm{~mm}$ respectively. Spatial patterns of PET is also influenced by topography, vegetation and soil types (Figure 4). It is low at high elevations basins compared lower areas. Snow fed basin has high PET compared to rain fed basin. It may be because the snow-free season, is extended in summer in higher elevations. The rise in air temperature during the baseline lead to changes in forms of precipitation, increase in snowmelt run-off and evapotranspiration rate in the basin. Availability of more water due to rise in temperature may lead to more ET in the near future. The crop water requirement will also rise due to warming.

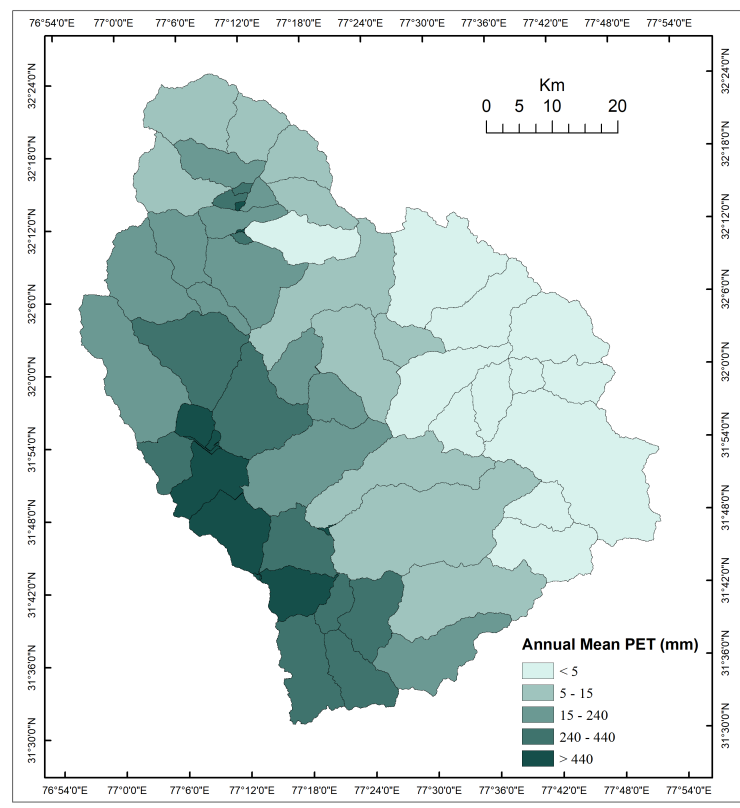

Figure 4. Distribution of annual mean PET in the basin during the baseline period (1974-2010)

PET increases linearly with the rise in mean air temperature compared to changes in rainfall because the former has direct effect. Slight increase in PET is found with increase in mean air temperature to $2^{0} \mathrm{C}(\mathrm{C} 1)$, by mid- $21^{\text {st }}$ century (Figure 5). However, with the rise in mean air temperature from $2^{0} \mathrm{C}$ to $3^{0} \mathrm{C}$, the annual PET will rise by 1 per cent in the near future. With an increase in rainfall under scenarios $\mathrm{C} 3$ and $\mathrm{C} 4$, PET found to be almost stable because mean air temperature under these scenarios was assumed constant. Slight increase has been observed in annual PET in scenarios C5 and C6 while it has shown a high rise under $\mathrm{C} 7$ and $\mathrm{C} 8$ scenarios because of the rise of $3^{0} \mathrm{C}$ in the later scenarios. Monthly PET shows fluctuations under the different climate change scenarios. It indicates a high increase of about 2 per cent; particularly in March and April under both $\mathrm{C} 1$ and $\mathrm{C} 2$ scenarios and it, demands may be fulfilled by early snow melting. Under the scenarios C3 and C4, the PET is almost negligible because of assuming constant air 
temperature. While in scenarios $\mathrm{C} 5$ and $\mathrm{C} 6$ in which mean air temperature $\left(2^{0} \mathrm{C}\right)$ and rainfall increases $(5$ and 10 per cent $)$ simultaneously, PET rises in winter and pre monsoon in the area by mid- $21^{\text {st }}$ century. Likewise, it has shown a rise under remaining scenarios, but the magnitude is higher because of $3{ }^{\circ} \mathrm{C}$ rise in temperature. The rise in PET during pre-monsoon due to rise in air temperature can be met by increase in snow free area.

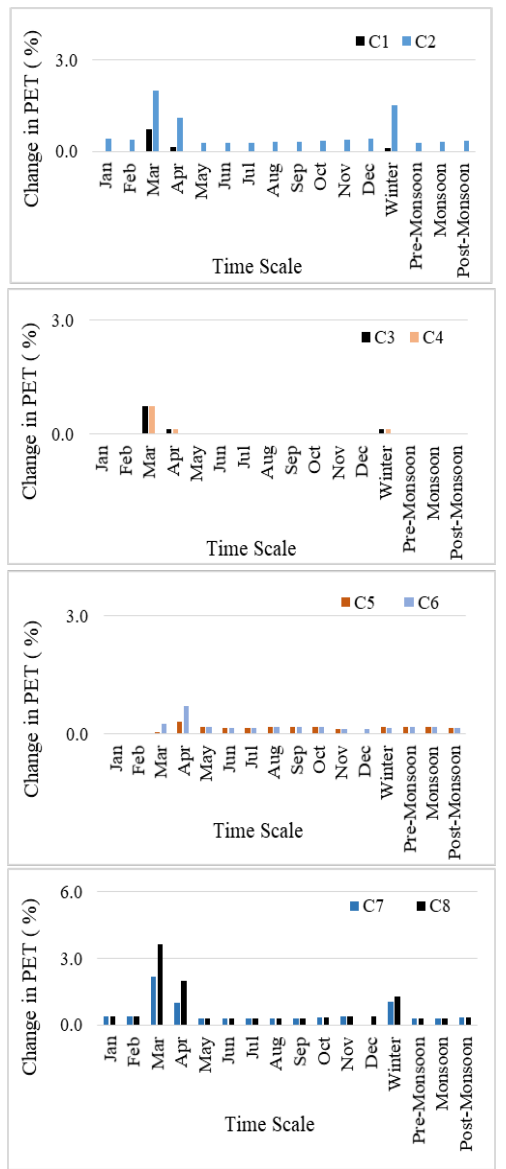

Figure 5. Percentage change in PET in the basin during different future climate change scenarios

Changes in both radiation and relative humidity can have important effects on PET in different seasons. PET variation in monsoon is dominantly regulated by radiation while in the winter and pre-monsoon, increases in PET can be because of decrease in relative humidity (Chattopadhyay and Hulme, 1997). The rise in temperature will leads to early snow melting in the area (Rani and Sreekesh, 2016) resulting in more water availability to meet PET requirements. This will reduce the gap between PET and actual ET. It also provides more energy for PET and water for vaporisation. Besides, an increase in temperature, it is likely to cause rise in evaporation rate from the snow-free area (Bengtsson, 1980). Another study also found a rise in PET in a basin of Western Himalaya though there is variation in the magnitude due to different physiographic and land cover conditions (Narsimlu et al., 2013). Singh and Bengtsson (2005) shown variations in the effect of warming on evaporation in different basins of Satluj River and found that in the complex basin (means basin receives water from rain, snow and glacier), the evaporation increased by $8-25$ per cent for the rise in temperature from 1 to $3^{0} \mathrm{C}$. It meets the rising PET demand. The increase in PET in the present study is influenced greatly by the rise in temperature. The effect of a rise in temperature will not be uniform across the basin due to high altitudinal variations within the basin. At higher altitudes, the impacts would be greater owing to less density of the atmosphere and the larger snow cover area. With rising air temperature, crop water requirement, but snow will starts melting early which will be beneficial for agriculture. Crop growth will increase because of higher photosynthetic activity under high temperature and water availability. Consequently, there will be an increase in crop productivity. However, warming may have marked implication on apple cultivation because variation in cropping conditions which needs to be studied.

Uncertainty in the simulated conditions, in the present study, is influenced by non-availability of climate data of higher altitudes. The simulation can be improved further by collecting climate, snow and hydro-meteorological parameters at different altitudinal levels. The model parameterization and calibration was done using discharge data at one location due to lack of data. Quantifying many of these uncertainties is challenging for a Himalayan basin due to lack of meteorological data. Therefore, there is need of more such study with more stations, climate data to understand the effect of warming on various agriculture of the Himalayan watershed.

\section{CONCLUSIONS}

Hydrological processes vary with altitude in basins located in the Himalayan region because of different physiographic and climatic conditions. In depth analysis of the effect of climate change on PET and its altitudinal variations are absent for the Himalayan watersheds having both snow cover and agricultural and/or horticultural activities. The present study tried to understand the probable changes in PET under eight climate change scenarios. It is found that PET in the basin is more sensitive towards changes in air temperature. PET is likely to increase in the study area under future warming, although this increase is found to be uneven among seasons. Highest rise in PET is found in pre and post-monsoon. Overall rise in PET in the basin can be up to 2 per cent by mid- $21^{\text {st }}$ century. This may have serious implications for agricultural growth if increases in PET are not compensated by sufficient water. In addition to warming, an increase in the snow free area will also be an important factor for increasing the evaporation in this basin that will meet the PET demand. Warming in the future will affect the agriculture growth and production. However, there is a need to study this effect in detail. The increase in PET will enhance the crop ET in the area, especially under increased rainfall and snow melting conditions. The increased snowmelt water availability under the increasing warming conditions will lead to enhanced growth and productivity of crops due to augmented photosynthetic activity. The area being dominated with horticultural crops along the valleys. There will be increase in the production of horticultural crops in near future. However, warming may impact the apple production in the long run. There is also need of understanding the influence of warming, particularly on horticulture (apple cultivation) as it also important livelihood of the area. This paper is able to simulate plausible changes in PET but results should be taken as an indicator. Uncertainty in PET estimation can be minimised with wider stations hydro-meteorological data.

\section{ACKNOWLEDGEMENTS}

Authors are thankful to United States Geological Survey (USGS) for providing the Landsat data. Authors are also 
grateful to Department of Space, Indian Space Research Organization and National Remote Sensing Centre for providing elevation data for the study.

\section{REFERENCES}

Abbaspour, K.C., 2015a. SWAT-CUP manual (SWAT
Calibration http://swat.tamu.edu/media/114860/usermanual_swatcup.pdf. (13 January 2014).

Abbaspour, K.C., Rouholahnejad, E., Vaghefi, S., Srinivasan, R., Yang, H., Kløve, B., 2015b. A continental-scale hydrology and water quality model for Europe: calibration and uncertainty of a high-resolution large-scale SWAT model. Journal of Hydrology. 524, pp. 733-752.

Arora, M., Goel, N., Singh, P., 2005. Evaluation of temperature trends over India. Hydrological Sciences, 50(1), pp. 81-93.

Bal, P.K., Ramachandran, A., Palanivelu, K., Thirumurugan, P., Geetha, R., Bhaskaran, B., 2016. Climate change projections over India by a downscaling approach using PRECIS. AsiaPacific Journal of Atmospheric Sciences, 52(4), pp. 353-369.

BBMB (Bhakra Beas Management Board) 1988. Snow hydrology studies in India with particular reference to the Satluj and Beas catchments. In Proceeding of Workshop on Snow Hydrology. Manali, India. pp. 1-14.

Bengtsson, L., 1980. Evaporation from a snow cover. Nordic Hydrology, 11, pp. 221-234.

Bhutiyani, M., Kale, V., Pawar, N., 2007. Long-term trends in maximum, minimum and mean annual air temperatures across the north western Himalaya during the twentieth century. Climate Change, 85(1-2), pp. 159-177.

Cartosat 1 Data User's Handbook. http://www.euromap.de/download/P5_data_user_handbook.pdf (20 December 2014).

Cartosat-1 DEM http://bhuvannuis.nrsc.gov.in/bhuvan/web/ (20 December 2014)

Census of India (CoI) 2011. Provisional population totals paper 1 of 2011: Himachal Pradesh. http://www.censusindia.gov.in/2011-provresults/prov_data_products_himachal.html (20 May 2015).

Chattopadhyay, N., Hulme, M., 1997. Evaporation and potential evapotranspiration in India under conditions of recent and future climate change. Agricultural and Forest Meteorology, 87, pp. 55-73.

Cheema, M.J.M., Bastiaanssen, W.G.M., 2010. Land use and land cover classification in the irrigated Indus Basin using growth phenology information from satellite data to support water management analysis. Agricultural Water Management Journal, 97, pp. 1541-1552.

Chu, T.W., Shirmohammadi, A., 2004. Evaluation of the SWAT model's hydrology component in the Piedmont physiographic region of Maryland. Transactions of ASAE. 47 (4), pp. 1057-1073.
Cohen, J., 1960. A coefficient of agreement for nominal scales. Educational and Psychological Measurement, 20(1), pp. 37-46.

Congalton, R.G., 1991. A review of assessing the accuracy of classifications of remotely sensed data. Remote Sensing of Environment, 37:35, pp. 35-46.

Dash, S., Hunt, J., 2007. Variability of climate change in India. Current Science, 93(6), pp. 782-788.

Dash, S., Jenamani, R., Kalsi, S., Panda, S., 2007. Some evidence of climate change in twentieth-century India. Climatic Change, 859(3-4), pp. 299-321.

Dimri, A.P., Dash, S., 2012. Wintertime climatic trends in the Western Himalayas. Climatic Change 111(3-4), pp. 775-800.

Feenstra, J.F., Burton, I., Smith, J.B., Tol, R.S.J., 1998. Handbook on methods for climate change impact assessment and adaptation strategies. http://lib.icimod.org/record/13767/files/7157.pdf. (24 August 2014).

Githui, F., Mutua, F., Bauwens, W., 2009. Estimating the impacts of land-cover change on runoff using the soil and water assessment tool (SWAT): case study of Nzoia catchment, Kenya. Hydrological Sciences Journal, 54(5), pp. 899-908.

Grusson, Y., Sun, X., Gascoin, S., Sauvage, S., Raghavan, S., Anctil, F., Sáchez-Pérez, J.M., 2015. Assessing the capability of the SWAT model to simulate snow, snowmelt and discharge dynamics over an alpine watershed. Journal of Hydrology, 531, pp. 574-588.

IPCC 2014. Climate Change 2014: Impacts, Adaptation, and Vulnerability. Part A: Global and Sectoral Aspects. Contribution of Working Group II to the Fifth Assessment Report of the Intergovernmental Panel on Climate Change [Field, C.B., V.R. Barros, D.J. Dokken, K.J. Mach, M.D. Mastrandrea, T.E. Bilir, M. Chatterjee, K.L. Ebi, Y.O. Estrada, R.C. Genova, B. Girma, E.S. Kissel, A.N. Levy, S. MacCracken, P.R. Mastrandrea, and L.L. White (eds.)]. Cambridge University Press, Cambridge, United Kingdom and New York, NY, USA, pp. 1132.

Islam, Z.-U., Rao, L., Zargar, H., Ahmad, S., Khan, M., 2008. Temperature variability in Himalayas and threat to the glaciers in the region: a study aided by remote sensing and GIS. Journal of Environmental Research and Development, 3(2), pp. 495505 .

Jain, S.K., Kumar, V., (2012) Trend analysis of rainfall and temperature data for India. Current Science, 102, pp. 37-49.

Jain, S., Goswami, A., Saraf, A., 2009. Role of elevation and aspect in snow distribution in Western Himalaya. Water Resource Management (23), pp. 71-83.

Krishnan, R., Sanjay, J., 2017. Climate change over INDIA: An interim report. Centre for climate change research. $\mathrm{http} / / / \mathrm{cccr}$. tropmet.res.in/home/old portals.jsp $\quad(20$ October 2017).

Kumar, V., Singh, P., Singh, V., 2007. Snow and glacier melt contribution in the Beas River at Pandoh Dam, Himachal Pradesh, India. Hydrological Sciences-Journal-des Sciences Hydrologiques, 52(2), pp. 376-388. 
Lirong, S., Jianyun, Z., 2012. Hydrological response to climate change in Beijiang River Basin based on the SWAT Model. Procedia Engineering, 28, pp. 241-245.

Liu, Z., Yao, Z., Huang, H., Wu, S., Liu, G., 2014. Land use and climate changes and their impacts on runoff in the Yarlung Zangbo river basin, China. Land Degradation and Development, 25, pp. 203-215.

Lu, E., Takle, E.S., Jha, M., 2009. The relationships between climatic and hydrological changes in the Upper Mississippi river basin: A SWAT and multi-GCM study. Journal of Hydrometeorology, 11, pp. 437-451.

Luo, Y., Ficklin, D., Liu, X., 2013. Assessment of climate change impacts on hydrology and water quality with a watershed modelling approach. Science of the Total Environment. 450-451, pp. 72-82.

Moriasi, D.N. Arnold, J.G., Van Liew, M.W., Bingner, R.L., Harmel, R.D., Veith. T.L., 2007. Model evaluation guidelines for systematic quantification of accuracy in watershed simulations. Transactions of the ASABE, 50(3), pp. 885-900.

Musau, J., Sang, J., Gathenya, J., Luedeling, E., 2015. Regional Hydrological responses to climate change in Mt. Elgon watersheds. Journal of Hydrology: Regional Studies. Pp. 1-14.

NASA Landsat Program 2014 Landsat TM LT51470381991320ISP00, L1T, Terrain Corrected, USGS, $11 / 16 / 1991$.

Nash, J., Sutcliffe, J., 1970. River flow forecasting through conceptual models: Part I. A discussion of principles. Journal of Hydrology. 10 (3), pp 282-290.

Neitsch, S., Arnold, J., Kiniry, J., Williams, J., 2011. Soil and Water Assessment Tool- Theoretical Documentation Version 2009. Texas: Texas Water resources Institute. http://swat.tamu.edu/media/99192/swat2009-theory.pdf $\quad(20$ May 2014).

Neitsch, S.L., Arnold, J.G., Kiniry, J.R., Srinivasan, R., Williams, J.R., 2002. Soil and Water Assessment Tool, User's Manual, Version 2000. http://swat.tamu.edu/media/1294/swatuserman.pdf (20 May 2014).

NRSC and ISRO 2011. Manual on "Preparation of Geo Spatial Layers Using High Resolution (Cartosat-1Pan+LISS-IV Mx) Orthorectified Satellite Imagery". Space Based Information Support for Decentralized Planning (SIS-DP), Remote Sensing and GIS Applications Area National Remote Sensing Centre, Indian Space Research Organisation (ISRO), Department of Space, Government of India, Hyderabad.

Pal, I., Al-Tabbaa, A., 2010. Long-term changes and variability of monthly extreme temperatures in India. Theoretical and Applied Climatology, (100), pp. 45-56.

Prasena, A., Shrestha, D.B.P., 2013. Assessing the effects of land use change on runoff in Bedog sub watershed Yogyakarta. Indonesian Journal of Geography. 45(1), pp. 48- 61.

Raneesh, K.Y., Santosh G.T., 2011. A study on the impact of climate change on discharge at the watershed scale in the humid tropics. Hydrological Sciences Journal, 56:6, pp. 946-965,
Rani, S., 2017. Effect of climate and land cover changes on discharge regime in the upper Beas river basin. $\mathrm{PhD}$. Thesis, submitted to Centre for the Study of Regional Development, Jawaharlal Nehru University, New Delhi.

Rani, S., Sreekesh, S., 2016. An analysis of pattern of changes in snow cover in the Upper Beas River Basin, Western Himalaya. In: Geostatistical and Geospatial Approaches for the Characterization of Natural Resources in the Environment. pp. 899-903.

Rani, S., Sreekesh, S., 2018. Variability of temperature and rainfall in the Upper Beas Basin, Western Himalayas. In: Climate change, extreme events and disaster risk reduction. pp. 101-120.

Rong, Y., Su, H., Zhang, R., Duan, Z., 2013. Effects of climate variability on evaporation in Dongping Lake, China, during 2003-2010. Advances in Meteorology, 65(19), pp. 153-156.

Singh, A., Gosain, A., 2011. Climate-change impact assessment using GIS-based hydrological modelling. Water International, 36(3), pp. 386-397.

Singh, P., Bengtsson, L., 2005. Impact of warmer climate on melt and evaporation for the rainfed, snowfed and glacierfed basins in the Himalayan region. Journal of Hydrology, 300(14), pp. 140-154.

Singh, P., Kumar, V., Thomas, T., Arora, M., 2008. Basin-wide assessment of temperature trends in northwest and central India. Hydrological Sciences Journal, 53(2), pp. 421-433.

SLUSI (Soil and Land Use Survey of India) 2013. Soil Resource Mapping District Kullu and Mandi, Himachal Pradesh, Soil and Land Use of Survey India.

Sood, A., Muthuwatta, L., McCartney, M., 2013. A SWAT evaluation of the effect of climate change on the hydrology of the Volta River basin. Water International, 38(3), pp. 297-311.

Tolson, B.A., Shoemaker, C.A., 2004. Watershed modeling of the Cannonsville basin using SWAT2000: Model. Cornell University, Ithaca, NY. https://ecommons.cornell.edu/bitstream/handle/1813/2710/2004 -2.pdf; sequence=1. (30 May 2014).

Tomer, M.D., Schilling, K.E., 2009. A simple approach to distinguish land-use and climate-change effects on watershed hydrology. Journal of Hydrology, 376(1-2), pp. 24-33. 